\title{
Pragmatisasi Pendidikan dalam Dunia Kerja
}

\author{
Nurul Malikah \\ Sekolah Tinggi Agama Islam Negeri Ponorogo \\ Email: malika_nur32@yahoo.co.id
}

\begin{abstract}
Vocational education as a part of the National Education system plays a strategic role for the realization of the skilled national labor. Because each vocational graduates is created to become good human resources, in the sense that when they have completed vocational school they able to apply the knowledge. But in fact, the graduates of vocational school is recognized only by itself school and still lack confidence in the business and industrial world. The old model of vocational education has disadvantage, is education model that was conducted unilaterally so that students left behind by the progress of the business/industrial world. Creating creativity and independence of the student is the right answer to avoid dependency and to reduce the unemployment rate. The Awareness of selfdevelopment by enhancing the students' confidence and self-reliance is an important part to prepare for the long-term goal achievement.
\end{abstract}

Keywords: vocational education, business world

\begin{abstract}
Abstrak
Pendidikan kejuruan sebagai salah satu bagian dari sistem Pendidikan Nasional, memainkan peran yang sangat strategis bagi terwujudnya angkatan tenaga kerja nasional yang terampil. Karena setiap lulusan SMK memang diciptakan untuk menjadi sumber daya manusia yang siap pakai, dalam arti ketika mereka telah menyelesaikan sekolahnya mereka dapat menerapkan ilmu yang telah mereka dapat sewaktu di sekolah. Namun pada kenyataannya, tamatan SMK hanya diakui oleh sekolah sendiri dan masih minimnya kepercayaan dunia usaha dan dunia industri. Pendidikan kejuruan model lama memiliki kelemahan yaitu, penyelenggaraan pendidikan secara sepihak sehingga anak didik tertinggal oleh kemajuan dunia usaha/dunia industri. Menciptakan kreativitas dan kemandirian siswa, merupakan jawaban tepat untuk menghindari ketergantungan dan dapat mengurangi tingkat pengangguran. Kesadaran mengembangkan diri dengan meningkatkan kepercayaan dan kemandirian siswa, merupakan bagian penting untuk mempersiapkan pencapaian tujuan jangka panjang.
\end{abstract}

Kata kunci: pendidikan kejuruan, dunia kerja.

ISSN 1979-1739

(C) 2014 Nadwa | IAIN Walisongo

http://journal.walisongo.ac.id/index.php/nadwa 


\section{A. Pendahuluan}

Pendidikan kejuruan adalah pendidikan di Indonesia yang mampu memberi sumbangan pada ekonomi nasional. Ada kurang lebih 200 program keahlian yang dilaksanakan di SMK-SMK di seluruh Indonesia. Bertolak dari peningkatan ekonomi dan pengurangan angka pengangguran, akhirnya penyelenggaraan program keahlian ini disesuaikan dengan kebutuhan lapangan kerja, baik untuk sektor formal maupun sektor nonformal.

Pendidikan kejuruan adalah salah satu sistem pendidikan yang memiliki peran penting, untuk mewujudkan tenaga terampil dan handal dalam menghadapi era globalisasi, yang ditakutkan tidak dapat terlewati oleh para generasi bangsa Indonesia. Inilah di antaranya pekerjaan yang harus diselesaikan, agar persaingan pasar tenaga kerja dari Sekolah Kejuruan meningkatkan standar kompetensi sesuai dengan permintaan pasar kerja dan dunia industri, bukan hanya pemenuhan tujuan kompetensi life skill sekolah yang mendapatkan dukungan pemerintah, agar eksistensi sekolah kejuruan tidak habis manis sepah terbuang karena tereduksi tantangan global.

Pada dasarnya pemerintah telah memberikan kesempatan sama kepada semua sekolah, dalam perolehan pembelajaran yang didukung dengan kebijakan bahwa sekolah kejuruan sebagai pemasok tenaga terdidik, yang mampu memiliki daya kreativitas dan gagasan terhadap konsep baru, dalam upaya perluasan kerja dan keanekaragaman dunia industri. Pembuktian ini melalui kecermatan dalam melihat peluang sebagai hasil dari kemampuan berpikir kritis dan berinisiatif, mencari jeda dan sela untuk dikembangkan menjadi lahan baru yang dapat menyerap tenaga kerja.

Berpikir kreatif dan kritis merupakan proses pembelajaran berkesinambungan dan terstruktur dengan pedoman kurikulum yang jelas dan kesesuaian standar evaluasi. Penetapan kurikulum yang lebih besar kaitannya dengan lapangan pekerjaan dimanfaatkan lembaga untuk menghasilkan output yang handal dan diterima di dunia industi, akan tetapi lembaga pendidikan kejuruan lebih sering terpaku pada teori, sehingga peserta didik kurang kreatif dan minim kompetensi.

Komponen dalam sistem pendidikan kejuruan memiliki porsi jelas untuk tidak meletakan kekeliruan ini pada komponen lainnya, sehingga saling menyalahkan jika terjadi hal yang tidak selaras dengan pedoman pendidikan kejuruan. Dengan demikian, perlu 
kiranya kita mengkaji tentang bagaimana sudut pandang filosofis dalam meresponsnya keberadaan Sekolah Kejuruan, sebagai solusi mengatur calon tenaga kerja kreatif yang meminimalisir tingginya angka pengangguran di usia produktif.

\section{B. Pandangan Filosofi terhadap Tujuan Pendidikan Ketenagakerjaan}

Pendidikan kejuruan adalah pendidikan yang menciptakan tenaga kerja yang terampil dan ahli dalam bidangnya, dengan cara membangkitkan kesadaran individu sehingga muncul keterampilan dan eksistensi individu. ${ }^{1}$ Keterampilan melalui pengalaman yang terus menerus yang menciptakan perubahan, ${ }^{2}$ pengalaman itu dinamis, temporal, spasial, dan pluralistis.

1. Pengalaman itu dinamis. Hidup itu selalu dinamis, menuntut penyesuaian secara terus-menerus dalam semua aspek kehidupan. Realita tersebut menuntut tindakan-tindakan dinamis yang bersifat alternatif-alternatif.

2. Pengalaman itu temporal. Seperti alam, kebudayaan pun mengalami perkembangan, mengalami perubahan dari waktu ke waktu. Pengalaman berawal, berlangsung dalam waktu, dan berakhir pula dalam waktu.

3. Pengalaman itu spasial. Pengalaman hanya akan terjadi di tempat-tempat yang tertentu saja yaitu lingkungan kehidupan manusia.

4. Pengalaman itu pluralistis. Pengalaman itu terjadi seluas adanya antarhubungan dan antaraksi manusia di mana individu itu terlibat. Subyek yang mengalami pengalaman menangkap dengan seluruh kepribadiannya, dengan rasa, karsa, pikir dan panca inderanya sehingga pengalaman itu bersifat pluralistik

Tampaknya pengalaman mencapai perubahan dalam mencapai tujuan, adalah bagian dari filsafat dengan aliran pragmatis yang bertujuan untuk menyiapkan peserta didik menghadapi masa depannya. Upaya pencapaian tujuan dimaksud adalah perlu ditanamkan disiplin dan membekalinya dengan berbagai keahlian

${ }^{1}$ Ali Maksum, "Paradigma Pendidikan Universal di Era Modern dan Post-Modern", dalam Mencari Misi Baru Atas Realitas Baru Pendidikan Kita”, (Yogyakarta: Pustaka Pelajar, 2003), hlm. 34.

${ }^{2}$ Noor Syam, Filsafat Pendidikan dan Dasar Filsafat Pendidikan Pancasila,(Jakarta: Rajawali Press,1984), hlm. 77. 
dan keterampilan. Pendidikan menurut pragmatisme, merupakan suatu proses reorganisasi dan rekonstruksi dari pengalaman-pengalaman individu. Untuk tercapainya tujuan tersebut, maka lembaga pendidikan harus mengontrolnya melalui kekuatan eksternal dengan cara membuang semua paksaan, membangkitkan kesadaran diri, melakukan aktivitas untuk mencapai keunggulan tertentu, dan harus mengetahui kecakapan dan minat. ${ }^{3}$

Menurut pandangan pragmatis, pendidikan adalah suatu proses pembentukan dari luar, dan juga bukan merupakan suatu pemberkahan kekuatan-kekuatan laten dengan sendirinya (unfolding). Dalam hal ini dapat dikatakan, baik anak maupun orang dewasa selalu belajar dari pengalamannya. Pragmatisme menyarankan untuk menguji kualitas nilai dengan cara yang sama, seperti kita menguji kebenaran pengetahuan. Harus diperhitungkan perbuatan manusia dengan tidak memihak, dan secara ilmiah memiliki nilai-nilai, yang tampaknya memungkinkan untuk memecahkan masalah-masalah yang dihadapi manusia. Nilai-nilai itu tidak akan dipaksakan dan akan disetujui setelah diadakan diskusi secara terbuka nilai lahir dari keinginan, dorongan, dan perasaan serta kebiasaan manusia, sesuai dengan watak sebagai kesatuan antara faktor biologis dan sosial dalam diri dan kepribadiannya. Nilai merupakan suatu realitas dalam kehidupan, yang dapat dimengerti sebagai suatu wujud dalam perilaku manusia, sebagai suatu pengetahuan dan sebagai suatu ide. ${ }^{4}$

Selanjutnya, John Dewey mengutarakan perlunya atau pentingnya pendidikan, karena berdasarkan atas tiga pokok pikiran yaitu:

1. Pendidikan merupakan kebutuhan untuk hidup. Pendidikan merupakan kebutuhan untuk hidup, karena adanya anggapan bahwa pendidikan selain sebagai alat, pendidikan juga berfungsi sebagai pembaharuan hidup. Dalam memenuhi kebutuhan hidup tersebut terjadi interaksi antara individu dengan lingkungannya, setiap individu dalam masyarakat bisa hancur, namun proses hidup akan berlangsung terus-menerus karena proses reproduksi.

2. Pendidikan sebagai pertumbuhan. Menurut Dewey, pertumbuhan merupakan suatu perubahan tindakan yang berlangsung

\footnotetext{
${ }^{3}$ Maksum, Paradigma Pendidikan Universal ..., hlm. 54.

${ }^{4}$ Juhaya S. Praja, Aliran-Aliran Filsafat dan Etika, (Bandung: Yayasan Piara, 1997), hlm. 9.
} 
terus-menerus untuk mencapai suatu hasil selanjutnya. Pertumbuhan ini terjadi karena belum matangnya individu.

3. Pendidikan sebagai fungsi sosial. Menurut Dewey, kelangsungan hidup terjadi karena self renewal. Kelangsungan sel frenewal ini pun terjadi karena pertumbuhan, karena pendidikan yang harus diberikan kepada anak-anak dan para pemuda di masyarakat. Yang dikenal dengan pendidikan demokratisasi. ${ }^{5}$ Demokratisasi adalah suatu modal kehidupan bersama sebagai suatu pengalaman yang saling mengisi dari setiap individu karena pertukaran pendapat, serta kebebasan mengungkapkan kemampuan pribadi yang berbeda-beda. Komitmen inilah yang mempersatukan kelompok sebagai kelompok dinamis dan kesepakatan yang dicapai merupakan kebanggaan untuk mewujudkan keadilan yang dikuasai dengan moralitas.

Dalam hubungan sekolah sebagai fungsi sosial, Dewey mengemukakan bahwa sekolah sebagai alat transmisi, merupakan suatu lingkungan yang memiliki tiga fungsi, yaitu:

a) menyederhanakan dan menertibkan faktor-faktor bawaan yang dibutuhkan untuk berkembang.

b) memurnikan dan mengidealkan kebiasaan masyarakat yang ada.

c) menciptakan suatu lingkungan yang lebih luas, dan lebih baik daripada yang diciptakan anak-anak tersebut dan menjadi milik mereka untuk dikembangkan. ${ }^{6}$

Pada akhirnya pendidikan adalah mengikuti peran pasar yang kompetensinya harus disesuaikan dengan permintaan pasar, sehingga dapat memuaskan pelanggan. Dengan demikian, pasar terhadap dunia pendidikan akhirnya muncul prinsip kompetensi untuk pemenuhan pasar, sebagimana disampaikan oleh Tilaar (2006), bahwa kompetensi harus dimiliki agar produk atau servis yang dilaksanakannya memberikan hasil yang sesuai dengan kebutuhan atau memenuhi serta memuaskan kebutuhan pelanggan. ${ }^{7}$ Dalam hal ini erat kaitannya, bahwa pengetahuan dan persepsi pelanggan secara tidak sadar dikuasai

5 H.A.R, Tilaar, Standarisasi Pendidikan Nasional: Suatu Tinjauan Kritis, (Jakarta: Rineka Cipta, 2006), hlm. 55.

${ }^{6}$ Uyoh Sadulloh, Pengantar Filsafat Penddikan, (Bandung: Alfabeta, 2007), hlm. 32.

${ }^{7}$ H.A.R Tilaar, Standarisasi Pendidikan Nasional ..., hlm. 25. 
oleh dunia permodalan di dunia bisnis. Sehingga pendidikan tidak lagi bertumpu pada idealisme pendidikan, untuk menguasai dan mengembangkan ilmu pengetahuan, untuk kemanusiaan, tetapi ilmu pengetahuan mengikuti perkembangan yang sesuai dengan selera modal besar, korporasi, dan kehidupan yang dangkal karena kurangnya pertimbangan moral, dan mengikuti cara hidup new life skill yang mengikuti cara hidup hedonistis.

Berdasarkan pendapat John Dewey, bahwa pengalaman adalah prioritas yang dapat memperbaiki kualitas manusia dengan menciptakan penemuan baru. Melalui kesadaran, pemahaman dan persepsi adalah titik tolak manusia dapat berubah. Perubahan yang didasari pemahaman permodalan dan investasi memotivasi percepatan kualitas hasil, yang didukung dengan sarana dan perhatian pemerintah. Kondisi ini tampaknya juga direspons sekolah kejuruan untuk memperluas ruang lingkup pendidikan kejuruan, untuk senantiasa memenuhi gerak dunia perindustrian yang terus berkelanjutan. Untuk menyeimbangkan tujuan yang berorientasi pada cara kesenangan atas prestasi yang dicapai maka beberapa tujuan pendidikan dalam orientasi Islam adalah:

a) untuk membantu pembentukan akhlak yang mulia. Islam menetapkan bahwa pendidikan akhlak adalah jiwa pendidikan Islam, dan bahwa mencapai akhlak yang sempurna adalah tujuan pendidikan sebenarnya.

b) persiapan untuk kehidupan dunia dan kehidupan akhirat. Pendidikan Islam tidak hanya menaruh perhatian pada segi keagamaan saja, dan tidak hanya menaruh perhatian pada segi dunia saja, tetapi ia menaruh perhatian pada keduanya dan ia memandang persiapan untuk kedua kehidupan itu sebagai tujuan tertinggi dan terakhir bagi pendidikan.

c) menumbuhkan ruh ilmiah pada pelajaran dan memuaskan keinginan hati untuk mengetahui dan memungkinkan ia mengkaji ilmu sekadar sebagai ilmu. Pada waktu pendidik-pendidik muslim menaruh perhatian pada pendidikan agama dan akhlak dan mempersiapkan diri untuk kehidupan dunia dan akhirat, mereka juga menumbuhkan perhatian pada sains, sastra, kesenian dalam berbagai jenisnya. 
d) menyiapkan pelajar dari segi profesional supaya dapat menguasai profesi tertentu, dan dapat mencari rezeki dalam hidup dengan mulia di samping memelihara segi kerohanian, keagamaan, dan akhlak. Selain itu, ia tak lupa melatih badan, akal, hati, perasaan, kemauan, tangan, lidah, dan pribadi.

e) persiapan untuk mencari rezeki dan pemeliharaan segisegi kemanfaatan. Pendidikan Islam tidaklah semuanya bersifat agama atau akhlak, atau spiritual semata-mata, tetapi menaruh perhatian pada segi kemanfaatan pada tujuan-tujuan, kurikulum dan aktivitasnya. ${ }^{8}$

\section{Konsep Pendidikan Kejuruan}

Pendidikan kejuruan sebagai salah satu bagian dari sistem Pendidikan Nasional, memainkan peran yang sangat strategis bagi terwujudnya angkatan tenaga kerja nasional yang terampil. Karena setiap lulusan SMK memang ditempa untuk menjadi sumber daya manusia yang siap pakai, dalam arti ketika mereka telah menyelesaikan sekolahnya, lulusan SMK tersebut dapat menerapkan ilmu yang telah mereka dapat sewaktu di sekolah dalam kehidupan nyata.

Tantangan era globalisasi saat ini, menuntut adanya kesiapan tenaga kerja yang memiliki kualifikasi yang berbeda dengan keadaan sebelumnya. Dengan jumlah angkatan kerja yang besar, diharapkan benar-benar mampu menyesuaikan diri agar dapat memiliki keunggulan yang kompetitif. Namun pada kenyataannya, tamatan SMK hanya diakui oleh sekolah sendiri dan masih minimnya kepercayaan dunia usaha dan dunia industri. Hal ini dikuatkan oleh Sidi, bahwa pendidikan kejuruan model lama memiliki kelemahan yaitu, penyelenggaraan pendidikan secara sepihak sehingga anak didik tertinggal oleh kemajuan dunia usaha atau dunia industri (DU/DI), tidak jelas kompetensi yang dicapai, tidak mengakui keahlian yang diperoleh di luar sekolah. ${ }^{9}$

Pendidikan merupakan salah satu faktor yang penting dalam pengembangan sumber daya pemuda, tidak saja mengubah pengetahuan, akan tetapi juga meningkatkan keterampilan serta

${ }^{8}$ Muayyin, Menjelaskan Tsiqoh, (Yogyakarta: Pustaka Pelajar, 2008), hlm. 77.

${ }^{9}$ Indra Djati Sidi, Menuju Masyarakat Belajar: Menggagas Paradigma Baru Pendidikan,(Jakarta: Paramadina, 2001), hlm. 137. 
kualitas kerja. Dari konsep ketenagakerjaan, fungsi pendidikan memiliki dua dimensi penting. Pertama, dimensi kuantitatif yang meliputi kemampuan sistem pendidikan sebagai pemasok tenaga kerja terdidik, atau untuk mengisi lowongan kerja yang tersedia. Kedua, dimensi kualitatif yang penghasil tenaga kerja terdidik yang selanjutnya dapat dibentuk menjadi tenaga penggerak pembangunan atau driving force for development.

Pendidikan kejuruan atau vokasi dalam perkembangan terminologinya disebut juga Occupational Education, Workforce Development Education (WDE), Career and Technical Education (CTE). Pendidikan kejuruan/vokasi sebagai pendidikan orang dewasa (adult education), didesain menyiapkan siswa/mahasiswa untuk memasuki dunia kerja, yang lebih dikenal dengan dunia usaha dan dunia industri. Dalam konteks ini pendidikan kejuruan/vokasi adalah pendidikan untuk bekerja (education for work). Istilah CTE lebih memberi makna bahwa pendidikan kejuruan/vokasi sebagai jenis pendidikan, yang tujuan utamanya adalah menjadikan individu siswa/mahasiswa siap pakai di dunia kerja.

1. Karakter Sekolah Kejuruan

Pendidikan kejuruan bertujuan untuk meningkatkan kecerdasan, pengetahuan, kepribadian, akhlak mulia serta keterampilan peserta didik untuk hidup mandiri dan mengikuti pendidikan lebih lanjut sesuai dengan program kejuruannya. Agar dapat bekerja secara efektif dan efisien serta mengembangkan keahlian dan keterampilannya, siswa sekolah kejuruan harus memiliki stamina yang tinggi, menguasai bidang keahliannya dan dasar-dasar ilmu pengetahuan dan teknologi, memiliki etos kerja yang tinggi dan mampu berkomunikasi sesuai dengan tuntutan pekerjaannya, serta mampu mengembangkan diri (UU No. 20 Tahun 2003).

Sekolah Menengah Kejuruan dapat menghasilkan tenagatenaga yang cerdas (smart), siap kerja dan kompetitif. Cerdas (smart) yang dimaksud bukan hanya cerdas secara intelektual, namun juga cerdas secara spiritual, emosional dan sosial, serta cerdas secara kinestetik. Siap kerja, karena lulusan SMK telah dibekali keterampilan dan kemampuan bekerja di bidangnya, sehingga mereka siap untuk langsung bekerja tanpa perlu ditraining lagi. Mereka juga dibekali kemampuan untuk bisa membuka usaha sendiri. Kompetitif, siswa SMK memiliki jiwa kompetitif yaitu ingin menjadi agen perubahan dan sikap 
pantang menyerah yang memang sudah ditanamkan sejak tahun pertama di SMK. Kemandirian serta kepribadian siswa SMK yang unggul memicu kesiapan mental untuk bekerja atau membuka lapangan usaha ketika lulus.

Keunggulan pendidikan kejuruan adalah kemampuannya memberikan peluang bagi siswa didik untuk mendapat proses pembelajaran dengan terjun langsung ke dunia usaha/industri, sehingga siswa memperoleh pengalaman yang nyata dan relevan dengan bidang kejuruan yang dipelajarinya, sekaligus memberi bekal keterampilan yang dibutuhkan.

2. Aspek Ketenagakerjaan

Pengertian tenaga kerja adalah semua orang yang bersedia untuk sanggup bekerja menghasilkan suatu output (hasil kerja), kemudian hasil kerja tersebut diukur dengan upah (penghasilan). Jika berbicara mengenai ketenagakerjaan tentu tidak terlepas dari produktivitas dan upah yang diperoleh seseorang dalam bekerja.

Dalam melakukan pembinaan dan pengembangan SDM melalui program pendidikan dan pelatihan kejuruan/profesi, perlu digaris bawahi bahwa human factor memang merupakan salah satu aspek penting dalam menghadapi pasar kerja global. Akan tetapi keunggulan faktor manusia yang secara populer disebut sebagai kualitas SDM yang kompetitif ini, tidak akan banyak berarti, apabila tidak disertai dengan pengembangan aspek-aspek lain seperti struktur pasar, organisasi perusahaan, hubungan industrial, maupun pengembangan manajemen keuangan dan manajemen SDM. Atau dengan kata lain, resources based strategy yang meliputi aspek sumber daya terwujud dan tidak terwujud, aspek keberhasilan yang meliputi ilmu pengetahuan, kohesi sosial, infrastruktur, konektivitas, dan produktivitas, serta aspek belajar yang terus menerus melakukan learning dan learning organization, merupakan aspek yang tidak dapat dipisahkan antara satu dengan yang lainnya, dalam melakukan pembinaan dan pengembangan SDM melalui pendidikan dan pelatihan kejuruan/profesi.

Semua pihak yang terkait dengan pelaksanaan pembinaan dan pengembangan pendidikan dan pelatihan kejuruan/profesi, termasuk keterlibatan dunia industri/dunia usaha dalam semua prosesnya, secara bersama-sama diharapkan dapat merubah pemikiran sektoral menjadi pemikiran nasional, dalam rangka 
mengejar dan membangun kualitas SDM yang memiliki kompetensi dan berdaya saing global.

Titik singgung antara pengembangan SDM dengan pasar kerja global, terlihat pada krusialnya posisi manusia sebagai subjek pengembangan. Yaitu manusia yang memiliki kreativitas dan inovasi, kompetensi (skill), dan sikap atau etos kerja (attitude). Dari titik singgung seperti ini hal yang menjadi pengalaman berharga adalah, adanya kesempatan untuk memiliki bidang kemampuannya melalui proses belajar (learning proces). Baik belajar untuk lebih efektif, efisien, maupun belajar dari kesalahan yang pernah dialaminya, karena hanya dengan proses belajar seperti inilah dapat dibangun kualitas SDM yang mampu bersaing di era global. ${ }^{10}$

Kualitas SDM dengan memiliki kompetensi yang didefinisikan sebagai gabungan dari sebagian keterampilan (skill), pengetahuan (knowledge), dan sikap (attitude). Keterampilan dapat diperoleh dari pendidikan atau pelatihan kejuruan/profesi yang dilakukan, dan dapat diprediksi dalam programprogramnya. Demikian pula hal sebaliknya. Sikap profesional angkatan kerja Indonesia perlu terus ditingkatkan dan dijaga semenjak mereka memasuki dunia pendidikan dan pelatihan, dengan cara menjauhkan dari pengaruh negatif agen-agen sosial di atas. Namun ketiga agen sosial di atas dijadikan cermin untuk mendorong pembinaan angkatan kerja secara dini menuju sikap profesional.

\section{Signifikasi Pendidikan dengan Dunia Kerja}

1. Ketenagakerjaan

Pendidikan vokasi menekankan pandangan pada manusia sebagai economic, tidak sebagai kultural. Ekspektasi budaya menyatakan semua manusia bekerja dan saya tahu manusia dari pekerjaannya. Kemampuan seseorang dalam bekerja lebih tinggi, nilai manusia lebih luas dari sekadar bekerja. Sehingga untuk pekerja lebih meningkatkan makna dirinya jika dapat

${ }^{10}$ Azua J and S. Azua, "Corporation Strategis for Defining Competitive Industrial Policies", Strategic Management Society Conference, (Orlando: 1996), hlm. 6. 
menciptakan pekerjaan. ${ }^{11}$ Tenaga kerja yang tidak terserap dalam lingkup dunia kerja dan industri, akan berdampak menjadi pengangguran, yang disebabkan karena penyimpangan kapitalisme sebagaimana yang telah diungkapkan, bahwa yang menciptakan kondisi adanya pengangguran adalah para kapitalis dan negara, yang mendukung para kapitalis dalam menentukan pilihan barang-barang yang akan mereka buat, dan dalam hal teknologi yang mereka pergunakan. ${ }^{12}$ Agar tidak terjadi kegagalan, maka pakar ekonomi pendidikan mengembangkan analisis kebutuhan akan tenaga kerja berdasarkan kebutuhan riil (demand) di pasar tenaga kerja, dan prospek lulusan dari dunia pendidikan (supply). Oleh sebab itu, survei yang dilakukan tidak hanya survei tenaga kerja oleh pengusaha, tetapi juga sistem pengangkatan pegawai, penghargaan pengalaman kerja sebagai pengganti sekolah formal, tersedianya kegiatan training, dan pola mobilitas internal dalam dunia kerja. Metode survei yang digunakan adalah "tracer study" atau "retrospective tracer study". ${ }^{13}$ Maka, pendidikan adalah salah satu investasi dalam sumber daya manusia, selain kesehatan dan migrasi. Pendidikan memberikan sumbangan secara langsung terhadap pertumbuhan pendapatan nasional, melalui peningkatan keterampilan dan produktivitas kerja. Keterampilan praktis yang dapat terserap pasar sesuai potensi ekonomi, dan kebutuhan ekonomi masyarakat, sehingga interaksi dengan pengetahuan dapat berdampak pada tingkat kemandirian yang diperlukan dalam kecakapan hidup dalam bekerja.

Ciri pembelajaran life skills adalah: 1) terjadinya proses identifikasi kebutuhan belajar, 2) penyadaran untuk belajar bersama, 3) keselarasan kegiatan belajar untuk mengembangkan diri, belajar, usaha mandiri, usaha bersama, 4) penguasaan kecakapan personal, sosial, vokasional, akademik, manajerial, kewirausahaan, 5) pemberian pengalaman dalam melakukan pekerjaan dengan benar, menghasilkan produk bermutu, 6)

${ }^{11}$ Thompson, JF. Foundations of Vocational Education, (New Jersey: Prentice Hall, 1973), hlm. 29.

${ }^{12}$ Martin Carnoy Umra, Carlos Torres, and Jeff Unsicker, Mexico, D.F: Ediciones Gernika, (Paris:International Institute of Educational Planning 1986), hlm. 79.

${ }^{13}$ Nurhadi, Kurikulum 2004: Pertanyaan dan Jawaban, (Jakarta: Gramedia, 2004), hlm. 88. 
interaksi saling belajar dari ahli, 7) penilaian kompetensi, dan (8) pendampingan teknis untuk bekerja atau membentuk usaha bersama. ${ }^{14}$

2. Lapangan Kerja

Lapangan kerja adalah bidang/jenis pekerjaan yang mampu memberikan kesempatan kepada seseorang melakukan aktivitas kegiatan untuk menghasilkan gaji. Lapangan pekerjaan ini terdiri dari berbagai sektor yaitu:

a. industri pengolahan.

b. pertanian, peternakan dan perikanan.

c. pertambangan dan penggalian.

d. listrik, gas dan air.

e. bangunan/konstruksi.

f. perdagangan, hotel dan restoran.

g. angkutan, pergudangan dan komunikasi.

h. keuangan, asuransi, usaha persewaan bangunan/tanah dan jasa perusahaan.

i. jasa kemasyarakatan, sosial dan perorangan.

Adanya permintaan tenaga kerja oleh perusahaan-perusahaan tentunya, merupakan peluang kesempatan untuk memperoleh pekerjaan bagi para pencari kerja. Karena kebijaksanaan perluasan kerja, erat hubungannya dengan kebijaksanaan kependudukan dan sumber utama penawaran tenaga kerja adalah penduduk. Tidak semua penduduk menawarkan tenaga kerjanya di pasar tenaga kerja, hal ini karena mereka lebih dulu mempertimbangkan kelayakan bekerja berdasarkan kesesuaian pekerjaan dengan upah yang diterimanya. Selain itu, kemampuannya untuk melakukan pekerjaan tersebut juga merupakan bahan pertimbangan baginya. Pernyataan ini menunjukkan bahwa tidak semua tenaga kerja atau penduduk dalam usia kerja siap bekerja.

Secara umum penyediaan tenaga kerja suatu negara atau daerah dipengaruhi oleh berbagai faktor seperti jumlah penduduk, tenaga kerja, pendidikan, perkembangan ekonomi dan lain sebagainya. ${ }^{15}$ Semakin sempitnya daya serap sektor modern terhadap perluasan kesempatan kerja, telah menyebabkan

${ }^{14}$ Satori, Profesi Keguruan, (Jakarta: Universitas Terbuka,2002), hlm. 28.

15 Sonny Sumarsono, Ekonomi Manajemen Sumber Daya Manusia \& Ketenagakerjaan, (Jember: Graha Ilmu, 2003), hlm. 41. 
sektor tradisional menjadi tempat penampungan angkatan kerja. Hal ini terjadi karena langkanya tenaga yang cukup terdidik, karena ekonomi industri membutuhkan tenaga kerja yang terdidik. Mutu angkatan kerja Indonesia dilihat dari keperluan proses industrialisasi sangat tidak memadai.

Dalam permintaan tenaga kerja biasanya perusahaan selalu memperhatikan dari berbagai aspek, salah satunya adalah bagaimana mengisi lowongan yang ada dengan orang yang sesuai. ${ }^{16}$ Jadi dalam hal ini, harus ada kesesuaian antara lowongan pekerjaan dengan tingkat pendidikan dan keterampilan dari calon tenaga kerja tersebut.

Jika berbicara mengenai tenaga kerja yang memiliki tingkat pendidikan dan keterampilan, maka kita dapat membedakan pasar tenaga kerja yang terdidik dan tidak terdidik. Pasar tenaga kerja terdidik adalah pasar tenaga kerja yang membutuhkan persyaratan dengan kualifikasi khusus, yang biasanya diperoleh melalui jenjang pendidikan formal dan membutuhkan waktu yang lama serta biaya pendidikan yang cukup besar. Sedangkan pasar tenaga kerja tidak terdidik merupakan pasar kerja yang menawarkan dan meminta tenaga kerja yang tidak membutuhkan kualifikasi khusus dan tingkat pendidikan yang relatif rendah.

Dari konsep ketenagakerjaan, fungsi pendidikan memiliki dua dimensi, pertama adalah kemampuan sistem dalam memasok tenaga kerja terdidik dan untuk mengisi lowongan kerja yang tersedia, kedua yaitu penghasil tenaga terdidik yang selanjutnya dapat dibentuk menjadi tenaga penggerak pembangunan. Maka diperlukan potensi manusia cerdas Indonesia yang tidak membedakan kepentingan kelompok, suku, agama, kepentingan sosial, maupun keanggotaannya dalam organisasi politik. Manusia cerdas Indonesia adalah manusia yang bertendensi moral Pancasila, yang direalisasikan dalam tindakan yang berdampak positif dan memiliki unsur nilai kerja keras, sehingga dapat menolong sesama manusia dalam kehidupan persaingan di era globalisasi. Unsur-unsur manusia cerdas di antaranya adalah:

\footnotetext{
${ }^{16}$ Sumarsono, Ekonomi Manajemen ..., hlm. 108.
} 
a. Manusia Indonesia cerdas adalah anggota masyarakat yang berbudaya. Kebudayaan yang dimilikinya tentulah kebudayaan yang beradab.

b. Bertalian erat dengan nilai-nilai Pancasila yaitu kepemilikan akan identitas Indonesia. Identitas Indonesia bukanlah identitas suku-suku, tetapi identitas dari Indonesia yang telah diperjuangkan bersama dalam revolusi 1945. Di dalam era globalisasi dewasa ini identitas suatu bangsa cenderung menghilang. Identitas suatu bangsa sangat perlu dalam menghadapi perubahan global yang sangat cepat.

c. Indonesia bukanlah suatu pengertian yang beku, tetapi sesuatu dinamis yang masih perlu dikembangkan dan dihidupkan. Indonesia sebagai suatu imagined community merupakan suatu perjuangan untuk mewujudkannya oleh setiap warga negara Indonesia. Penghayatan serta tindakan berdasarkan nilai-nilai Pancasila harus terus digalakkan di dalam setiap situasi pendidikan formal, informal dan nonformal.

d. Manusia Indonesia cerdas haruslah mempunyai orientasi terhadap perubahan global. Salah satu tuntutan di dalam perubahan global tersebut ialah harus memiliki pengetahuan dan keterampilan, sehingga dapat bersaing dan bekerja sama dengan bangsa-bangsa lain. Manusia Indonesia sebagai warga negara dunia, haruslah mempunyai daya saing yang setara dengan bangsa lain. Hal ini hanya dapat dicapai melalui kualitas pendidikan nasional yang tinggi.

e. Manusia yang cerdas adalah manusia yang mandiri. Manusia mandiri pertama-tama haruslah mempunyai kemampuan intelegensi yang terasah. Sebagai manusia mandiri, dia merupakan akan warga negara Indonesia yang tidak tergantung kepada utang luar negeri, ataupun belas kasihan karena pertimbangan-pertimbangan politik dari negara lain.

f. Manusia yang cerdas bukan hanya mempunyai kemampuan intelegensi yang tinggi, karena telah dikembangkan tetapi juga disertai dengan pertimbangan-pertimbangan moral. Moral kehidupan bersama di dalam lingkungan keluarga serta masyarakat sekitar (indigenious values). Tanpa moralitas, seorang yang cerdas dapat mengarah kepada kerakusan dalam kehidupan ekonomi global yang didominasi oleh 
prinsip-prinsip mencari keuntungan. ${ }^{17}$ Manusia cerdas tanpa moral adalah manusia yang rakus yang dapat bersifat penggelapan terhadap hak-hak asasi manusia, dan nilai-nilai kebersamaan umat manusia.

\section{E. Penutup}

Pendidikan, belajar dan bekerja adalah kesatuan komponen yang berawal dari pengalaman dengan titik tolak investasi terhadap kegiatan pembelajaran. Hasil pendidikan harus mempermudah dalam mencapai pekerjaan yang linear telah berkembang di masyarakat luas. Antisipasi dengan tidak adanya korelasi inilah yang diwaspadai untuk mempertahankan kepercayaan masyarakat terhadap hasil pendidikan di sekolah kejuruan. Masyarakat cukup berpengalaman menyikapi ketimpangan demand dan supply. Hal inilah akhirnya terlalu banyaknya pertimbangan untuk mengeluarkan anggaran biaya, karena tidak adanya jaminan jelas setelah melakukan aktivitas belajar. Pemerintah lagi menjadi tumpuan untuk mencarikan alternatif penyelesaian masalah.

Penyelesaian masalah adalah sumber manusia dapat beraktivitas jelas melalui ide dan gagasannya. Tanpa harus mencari kekurangan orang lain, akan tetapi memperbaiki kondisi agar lebih baik. Dalam pembelajaran sekolah kejuruan adalah membimbing siswa melakukan sesuatu untuk mendapatkan pengalaman, yang berakibat pada perubahan karena kreativitas dan inovasi yang dilakukan secara mandiri. Kemandirian belajar atas kecerdasan yang dikembangkan selaras dengan perjalanan globalisasi yang tidak dapat ditolak, karena salah satu sumber penciptaan kreativitas yang selaras dengan perkembangan teknologi global. Dampak kesejahteraan tidak serta merta membangkitkan perilaku hedonism yang mentoleransi segala upaya untuk mencapai tujuan tetapi justru menjadi tolok ukur manusia dalam mengembangkan kreativitas sosial untuk kesejahteraan di masyarakat. Menciptakan kreativitas mandiri dalam pandangan pragmatis, merupakan jawaban tepat untuk menghindari ketergantungan dan peningkatan tingkat pengangguran. Kesadaran mengembangkan diri dengan meningkatkan kepercayaan mandiri, merupakan bagian dari dinamisasi manusia dalam mempersiapkan tujuan jangka panjang.

${ }^{17}$ Tilaar, H.A.R, Standarisasi Pendidikan Nasional ..., hlm. 66. 


\section{Kepustakaan}

Azua J and S. Azua, "Corporation Strategis for Defining Competitive Industrial Policies", Strategic Management Society Conference, (Orlando: 1996).

Djojonegoro, Wardiman, Pengembangan Sumberdaya Manusia: Melalui Sekolah Menengah Kejuruan (SMK), (Jakarta: Balai Pustaka, 1999).

Hamalik, Oemar, Pengembangan Sumber Daya Manusia Manajemen Pelatihan Ketenagakerjaan: Pendekatan Terpadu, (Jakarta: Bumi Aksara, 2000).

Maksum, Ali, "Paradigma Pendidikan Universal di Era Modern dan Post-Modern", dalam Mencari Misi Baru Atas Realitas Baru Pendidikan Kita, (Yogyakarta: Pustaka Pelajar, 2003).

Sadulloh, Uyoh, Pengantar Filsafat Penddikan, (Bandung: Alfabeta, 2007).

Saud, Syaefudin, dkk., Perencanaan Pendidikan Suatu Pendekatan Komprehenshif, (Bandung: Program Pascasarjana UPIRemaja Rosdakarya, 2007).

Suustaapmarsono, Sonny, Ekonomi Manajemen Sumber Daya Manusia \& Ketenagakerjaan, (Jember: Graha Ilmu, 2003).

Surya, Aldwin, Perubahan Sosial Masyarakat Kota Metropolitan. (Medan: Kopertis Wilayah I, 2006).

Tilaar, H.A.R., Standarisasi Pendidikan Nasional: Suatu Tinjauan Kritis, (Jakarta: Rineka Cipta, 2006).

Thompson, J.F., Foundations of Vocational Education, (New Jersey: Prentice Hall, 1973). 